\title{
„A VÁlLALATI IGÉNYEK FIGYELEMBEVÉTELE AZ EGYETEM ELEMI ÉRDEKE.” INTERJú Dr. NAgY SÁNDOR GyUlával, a BCE BESZÁLlító- ÉS IPARFEJLESZTÉSI KUTATÓKÖZPONT VEZETŐJÉVEL, A BCE VÁLLALATI ÉS INTÉZMÉNYI KAPCSOLATOK FŐTANÁCSADóJÁVAL
}

1. A Budapesti Corvinus Egyetem megújulásának egyik fontos eleme az egyetem intézményi és vállalati kapcsolatainak megerősítése. ennek érdekében 2019 végén létrejött a Vállalati és Intézményi Kapcsolatok Igazgatóság nevü szervezeti egység. Hogy látja, mi hívta életre, és mik az idei első lépések, célok?

A Corvinus oktatói közül soknak van kiváló vállalati vagy (kormányzati) intézményi kapcsolata, azonban ezeket mindenki saját maga ápolja, építi vagy épp ennek ellenkezője. Sok kolléga hív meg óráira az üzleti életből vagy minisztériumokból, nemzetközi szervezetekből vendégelőadókat, küld ki gyakornoki felhívásokat, állásajánlatokat hallgatóinak. Ez eddig jellemzően szívességi alapon müködött, miközben ez a vállalat/intézmény számára megjelenési lehetőség, reklám vagy épp fejvadász szolgáltatás, mely mind értéket jelent. Az új egyetemi vezetés szükségét látta egy olyan csapat felállításának Stukovszky Tamás vezetésével, mely ezen kapcsolatokat számontartja, nyomon követi és rendszerszinten folyamatosan ápolja, mi több, az egyetem szolgáltatásait (pl. megjelenés, oktatás, kutatás) esetleg értékesíteni is tudja. Egyes intézetekben, karokon vannak olyan - az elmúlt években kialakult - jó gyakorlatok, melyeket meg kell őrizni, vagy ki lehet terjeszteni az egész egyetemre akár egy továbbfejlesztett formában. Az ezzel kapcsolatos egyeztetések folyamatosan zajlanak, és 2020 első negyedévének végére a tervek szerint már egy jól müködő rendszer és csapat kerülhet kialakításra.

2. Milyen nemzetközi példákat lehet találni a jól müködő kapcsolatrendszerre? Mi a követendő példa a Corvinus számára, ha van egyáltalán ilyen?

Rengeteg nemzetközi (London School of Economics, Technische Universität München, Wirtschaftsuniversität Wien, Universität Passau, Tallinn University of Technology) és hazai (a győri SZIE vagy a BME) jó példa van, azonban ezeket nem lehet csak egyszerüen lemásolni. Az egyes jó gyakorlatokat mérlegelés után adaptálni kell/lehet a Corvinuson, amennyiben az megfelel az egyetem hosszú távú céljainak.

Az egyik legérdekesebb példa talán a Tallinni Egyetem, ahol a hallgatók nemcsak müszaki, hanem gazdasági, informatikai, technológiai és szociológiai kérdéskörökben is végeznek közös projekteket KKV-kal és nagyvállalatokkal, valamint állami és egyéb intézményi szervezetekkel egyaránt. Ezek a projektek megfelelnek a jelenkor piaci helyzetének, felismerik az aktuális lokális (pl. Smart City koncepció) valamint világszintű (pl. megújuló energiaforrások) problémákkal és foglalkoznak azokkal. Olyan kérdésköröket boncolgathatnak a hallgatók, amely a jelenkor kihívásait rejtik magukban, és ezáltal mégis a jövőt építik. Mindezt úgy tehetik meg, hogy az egyetemen megszerzett lexikális tudást kiegészíti a legfejlettebb technológia, amely számukra egy erre a célra létrehozott laborkomplexumban a TalTech-ben található. A létesítményt az összes egyetemi

DOI:10.14267/RETP2019.04.28 
céges partner is használhatja, és így a vállalati kultúra teljes mértékben találkozik az egyetemi élettel, egymás igényeivel, és egy teljesen egyedülálló vállalati-egyetemi ökoszisztémát képeznek.

3. Az együttmüködések során mindig fontos kérdés az akadémiai szféra szabadsága és az intézményi-vállalati igények közötti összhang megtalálása. Jelenleg megvan ez az összhang? Ha nem, akkor hogyan lehet megtalálni?

Az egyetemi struktúra átalakítása és a piaci igények felé történő hangsúlyos elfordulás szükségessé teszi az egyes szakok tartalmi felülvizsgálatát, melyet az egyetem illetékes oktatási vezetése (oktatási rektorhelyettes, dékánok és szakfelelősök) meg is tesz. Az intézményi és vállalati kapcsolatokért felelős kollégák pedig közvetítenek ehhez vállalati igényeket, melyek figyelembevétele az egyetem elemi érdeke. Ennek beépítése az oktatásba (forma, tartalom) már az akadémiai függetlenség része, azonban vannak olyan egyetemi partnerek, akik ebben segítséget tudnak adni akár a tartalmi, akár az eszközoldalon. Ezt azonban minden esetben egyedileg, a szakfelelőssel és az egyetem vezetésével együtt kell mérlegelni.

4. A vállalati és intézményi együttmüködés során milyen új formák merülhetnek fel a kutatásban és az oktatásban? Mire van igénye a vállalatoknak és a különböző gazdaságpolitikai intézményeknek, és ezeket hogyan lehet implementálni az egyetem életébe?

A más egyetemeken működő példák közül nagyon szeretnénk olyan együttmüködéseket kialakítani egy-egy nagyobb hazai vagy nemzetközi céggel, ahol például egy választható tárgy vagy szakirány dedikáltan egy vagy több partnerintézménnyel együttmüködésben kerül kialakításra. Itt a partnerintézmény a képzési program kialakításában, a tananyag fejlesztésében és oktatásában is részt vehet, biztosítva ezzel a hallgatók gyakorlatorientált fejlesztését és segítve jövőbeni elhelyezkedésüket.

A felsőoktatási kooperációk területén az Audi Hungaria Zrt. és a győri Széchenyi István Egyetem az együttmüködés egyedülálló formáját valósítja meg. A vállalat a győri egyetemmel karöltve 2015-ben megalapította az Audi Hungaria Jármümérnöki Kart, mellyel elősegíti a hazai mérnökképzés fejlesztését, a tudományos kutatómunkát és a szakember-utánpótlás biztosítását. A vidéki egyetemek vállalati együttmüködése azonban nagyban eltér a fővárosiakétól. Győr esetében a vállalat fontos része a város fejlődésének, a város életének szerves részét alkotja. Az Audi Hungaria Zrt. számára természetes az a szerepvállalás, mely az oktatás támogatásával a város és a városba érkező fiatalok életminőségét javítja. Budapesten ez nagyobb kihívás, de mindenképp követendő példa.

\section{Köszönöm a beszélgetést!}

Trautmann László 